\title{
NON-LIMITED EMISSIONS DURING GLYCERINE COMBUSTION
}

\author{
Marek PATSCH, Peter PILÁT•
}

\begin{abstract}
The glycerine combustion is very problematic and difficult realizable because of its bad physical and chemical properties. The aim of article is measuring and evaluation of concentration of non-limited harmful pollutants during glycerine combustion in experimental burner. The main dangerous emissions which were measured were concentrations of acrolein and formaldehyde.
\end{abstract}

\section{INTRODUCTION}

The combustion from chemical aspect is fuel oxidation which can perform in any temperature. Glycerine combustion is very problematic and complicated due to its high viscosity, low pressure of vapour, high temperature of auto-ignition, and fears from production of dangerous emissions. The main dangerous emissions are aldehydes and ketones. The main representatives of aldehydes are formaldehyde and acrolein. Antecedent attempts showed that the most suitable means for glycerine combustion was burner usage. The burner has to be modified to be able to effective work with this type of fuel. The most important process during glycerine combustion in burner is fuel atomization. Three types of burner nozzle for glycerine were tested for glycerine atomization. Each with the same standardized capacity, same fuel spray angle. But the spray pattern was different. The nozzles had hollow, semi-solid, and solid spray pattern. Influence of spray pattern was surveyed.

\section{EXPERIMENTAL BURNER}

Experimental burner for glycerine combustion was two-fuel axial swirl burner with mechanical principle of glycerine atomization. It contained two fuel lines, for glycerine and for supporting fuel.

The supporting fuel was gaseous propane-butane. The supporting fuel had to heat up the combustion chamber (about $300^{\circ} \mathrm{C}$ ) before injection of glycerine and stabilize glycerine combustion.

Problems with high viscosity of glycerine were eliminated by means of preheating. Preheating reduced viscosity of glycerine and improved fuel processing. The fuel line for glycerine contained two preheaters, first preheater was in fuel tank, and second was before fuel nozzle. Second preheater was integrated into compact nozzle holder body and preheated glycerine to temperature $90^{\circ} \mathrm{C}$.

\footnotetext{
- Ing. Marek PATSCH, PhD., University of Žilina, Faculty of mechanical engineering, Department of power engineering, Univerzitná 1，010 26 Žilina, Slovakia. marek.patsch@fstroj.uniza.sk Ing. Peter PILÁT, PhD., University of Žilina, Faculty of mechanical engineering, Department of power engineering,Univerzitná 1, 01026 Žilina, Slovakia. peter.pilat@fstroj.uniza.sk
}

This is an Open Access article distributed under the terms of the Creative Commons Attribution License 2.0, which permits unrestricted use, distribution, and reproduction in any medium, provided the original work is properly cited. 
The burner is in the figure 1. The burner had one axial and four tangential combustion air inlets. This design insure large swirl zone with zone of recirculation in combustion chamber. CFD model of air and exhaust gases flow is in the figure 2 . The combustion chamber was cylindrical, made from fire-clay and later from stainless steel. Fire-clay did not resist thermal stress and combustion chamber had to be replaced with combustion chamber from stainless steel.

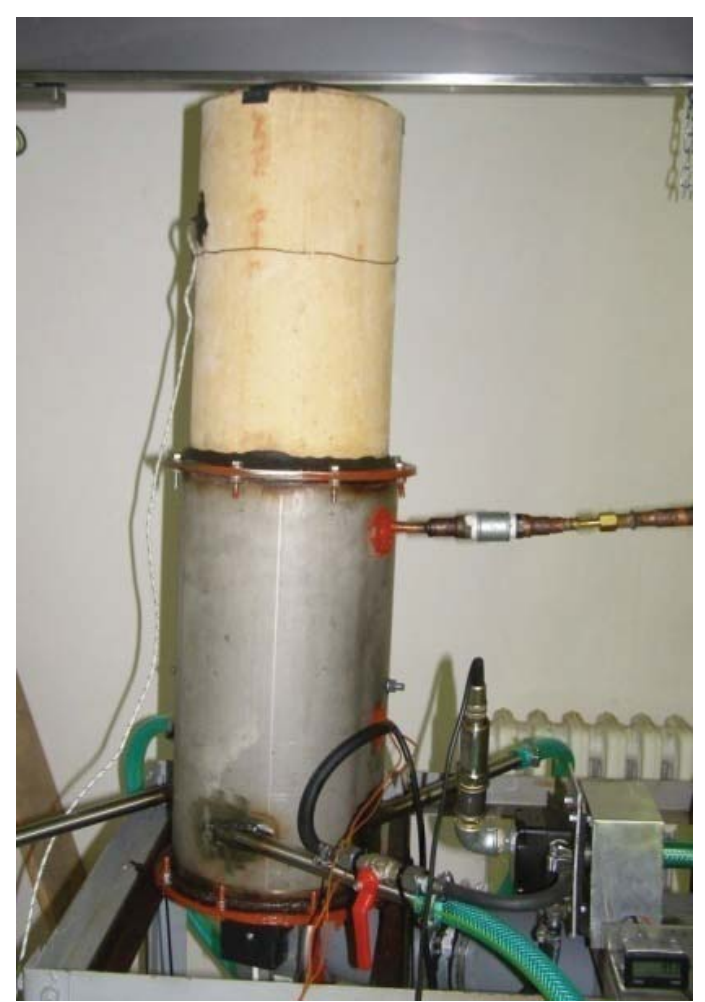

Figure 1: Experimental burner

\section{MEthod OF EMISSIONS MEASUREMENT}

Emissions were measured via continual analyzer MADUR GA-40 T. It measured concentrations of $\mathrm{CO}, \mathrm{CO}_{2}, \mathrm{O}_{2}, \mathrm{NOx}$ and unburned parts. Concentrations of formaldehyde and acrolein were measured via sampling pump with detection tubes. The detection tube contains reagent which reacts to given chemical substance. This method is very quick; precision of this method is satisfactory for this application.

\section{INFLUENCE OF SPRAY PATTERN}

The spray pattern influences on process of combustion, mixing droplets of fuel with combustion air, flame stability, combustion noise and vibrations.

The three nozzles with same standardized capacity $4,45 \mathrm{~kg} \cdot \mathrm{h}^{-1}$, and same fuel spray angle $45^{\circ}$ were used. The spray pattern was different. The nozzles had hollow (OD-H), semi-solid (OD-B), and solid (OD-S) spray pattern.

The conditions of measurement:

- Fuel rate 5,8 I. $\mathrm{h}^{-1}$

- Fuel pressure 1,5 $\mathrm{MPa}$

- Excess-air coefficient 2,2 
- Glycerine temperature $90^{\circ} \mathrm{C}$

- Distribution of combustion air was: $50 \%$ of total air was supplied by tangential inlet and $50 \%$ by axial inlet.

\section{RESULTS OF MEASUREMENTS}

Results of measurements are shown in table 1 . The steadiest combustion process was reached with nozzle OD-H with hollow cone. It was even though the temperature in combustion chamber was lower. This nozzle provides short flame which was suitable for given dimensions of combustion chamber (Figure 3). Nozzles with semi-solid (Figure 4) and solid cone (Figure 5) provide long flame. The flame length influenced temperature of exhaust gases because the flame taxied outwards from combustion chamber, closer to the measuring points. Higher values of residual $\mathrm{O}_{2}$, higher values of $\mathrm{CO}$, and lower values of $\mathrm{CO}_{2}$ suggest to non-ideal combustion process with nozzles with semi-solid and solid cone usage. Increase of NOx concentration incidental to increase of temperature in combustion chamber. The volume concentrations of acrolein and formaldehyde reached the lowest values when we used nozzle with hollow cone. The concentrations of acrolein and formaldehyde increased when we used other nozzles. The nozzle with semi-solid cone was absolutely improper because concentration of formaldehyde in exhaust gases was over maximal range of detection tube. The flame was very unstable and it pulsated. Flame pulsation proved in increase of combustion noise and in large vibration of testing stand. The cause of this case was bad mixture formation of glycerine and combustion air. The results of measurement show that using of nozzle with hollow cone is optimal for glycerine combustion.

Table 1: Results of exhaust gases compositions measurements

\begin{tabular}{|c|c|c|c|}
\hline & $\begin{array}{l}\text { Nozzle OD-H, } 45^{\circ}, \\
4,45 \mathrm{~kg} \cdot \mathrm{h}^{-1}\end{array}$ & $\begin{array}{l}\text { Nozzle OD-B, } 45^{\circ} \\
4,45 \mathrm{~kg} \cdot \mathrm{h}^{-1}\end{array}$ & $\begin{array}{l}\text { Nozzle OD-S, } 45^{\circ}, \\
4,45 \mathrm{~kg} \cdot \mathrm{h}^{-1}\end{array}$ \\
\hline $\begin{array}{l}\text { Average temperature } \\
\text { in combustion } \\
\text { chamber }\left[{ }^{\circ} \mathrm{C}\right]\end{array}$ & 692,2 & 786,0 & 805,7 \\
\hline $\begin{array}{l}\text { Temperature of } \\
\text { exhaust gases }\left[{ }^{\circ} \mathrm{C}\right]\end{array}$ & 633,7 & 660,6 & 786,5 \\
\hline $\mathrm{O}_{2}[\%]$ & 8,06 & 12,20 & 10,28 \\
\hline $\mathrm{CO}_{2}[\%]$ & 7,58 & 6,48 & 6,28 \\
\hline $\mathrm{CO}[\%]$ & 0,92 & 1,80 & 1,61 \\
\hline NO [ppm] & 68 & 47 & 42 \\
\hline $\mathrm{NO}_{2}[\mathrm{ppm}]$ & 11 & 124 & 106 \\
\hline NOx [ppm] & 79 & 171 & 148 \\
\hline$\lambda[-]$ & 2,17 & 2,2 & 2,01 \\
\hline Acrolein [ppm] & 50 & 400 & 200 \\
\hline Formaldehyde [ppm] & 400 & over maximal range & 1500 \\
\hline Fuel pressure [MPa] & 1,53 & 1,51 & 1,52 \\
\hline
\end{tabular}




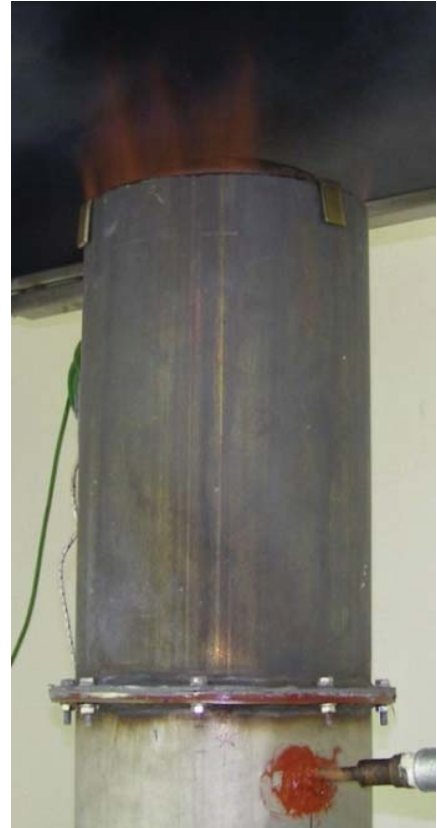

Figure 3: Nozzle OD-H

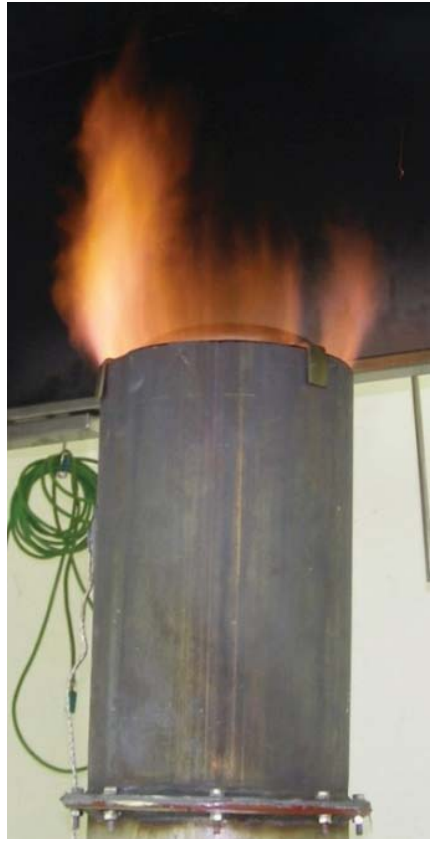

Figure 4: Nozzle OD-B

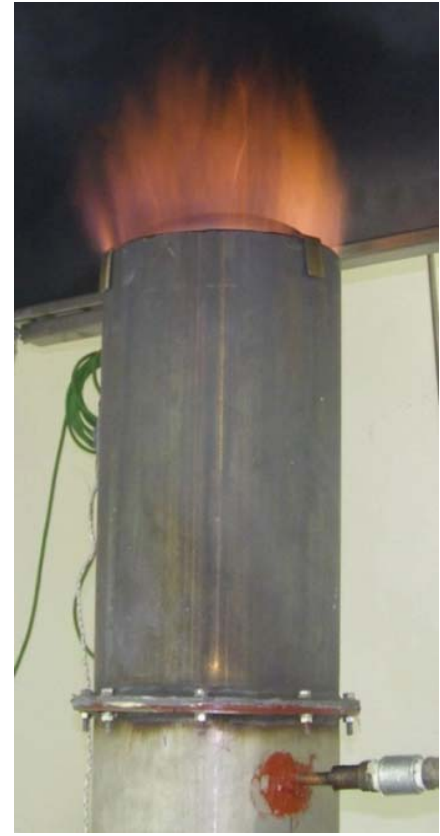

Figure 5: Nozzle OD-S

\section{CONCLUSION}

The steadiest combustion process was reached with nozzle OD-H with hollow cone. We reached the best flame stability and low emissions with this type of nozzle. Other nozzles did not provide combustion process with required quality and measured emissions were advanced. The nozzle with semi-solid cone was absolutely inconvenient to glycerine combustion. The concentration of acrolein and formaldehyde is still dangerous to health, because of this; the further research will be directed to optimization of combustion process and to reduction of acrolein and formaldehyde concentration in exhaust gases. Optimization will be directed to dimension of combustion chamber, and its heat losses, optimization of fuel-air mixture preparation.

\section{ACKNOWLEDGMENT}

This work is supported by the financial assistance of the project VEGA c. $1 / 0656 / 10$ "Výskum stability plameňa v horákoch energetických zariadení".

\section{REFERENCES}

[1] Ashgriz, N.: Handbook of Atomization and Sprays. Theory and Application, Springer, London, 2011.

[2] Baukal, CH. E., Jr.: Industrial Burners handbook, CRC Press, London, 2003.

[3] Baukal, CH. E., Jr.: Oxygen-enhanced combustion, CRC Press, London,1998.

[4] Bell, A. A., Jr.: HVAC Equations, Data, and Rules of Thumb. Second Edition, McGraw Hill, New York, 2008.

[5] Brumbaugh, J. E.: Audel HVAC Fundamentals. Volume 2, Heating System Components, Gas and Oil Burners, and Automatic Controls, $4^{\mathrm{TH}}$ Edition, Wiley Publishing, Inc., Indianapolis, 2004.

[6] El-Mahallawy, F., El-Din Habik, S.: Fundamentals and Technology of Combustion, Elsevier, Inc., Boston, 2002. 
[7] Glassman, I., Yetter, R. A.: Combustion. Fourth Edition. San Diego: Academic Press - Elsevier, San Diego, 2008.

[8] Keating, E. L.: Applied Combustion. Second Edition, CRC Press, New York, 2007.

[9] Niessen, W. R.: Combustion and Incineration Processes. Third Edition, Revised and Expanded, Marcel Dekker, Inc., Basel, 2002.

[10] Pagliaro, M., Rossi, M.: The Future of Glycerol. New Uses of a Versatile Raw Material, RSC Publishing, Cambridge, 2008.

[11] Peters, N.: Turbulent Combustion, Cambridge University Press, Cambridge 2000.

[12] Schwarz, A., Janicka, J.: Combustion noise, Berlin: Springer, Berlin, 2009. 